\title{
Selective Washing
}

National Cancer Institute

\section{Source}

National Cancer Institute. Selective Washing. NCI Thesaurus. Code C159889.

A procedure to collect the fluid from selected body sites in order to sample cells for cytology. 